\title{
Contemporary Features of Innovative Development of the Russian Mineral Resource Complex
}

\author{
Valeriy A. Kryukov and Anatoliy N. Tokarev \\ Institute of Economics and Industrial Engineering of SB RAS \\ 17 Akademika Lavrent'eva, Novosibirsk, 630090, Russia
}

Received 23.10.2019, received in revised form 02.12.2019, accepted 09.12.2019

\begin{abstract}
As of now, the mineral resource complex (MRC) is playing a crucial role in the Russian economy. In a situation when the resource base is becoming problematic and the economy of knowledge begins to hold sway, the stability and competitiveness of the complex will depend on innovative technological development in many ways. The factor that is becoming ever more crucial for the MRC is the use of new knowledge and technologies: the rights to results of intellectual work, technologies that allow extraction and economic exploitation of scarce and hard-to-reach resources.
\end{abstract}

The conducted analysis has revealed that the Russian MRC currently demonstrates low innovation activity and lacks new technologies conducive to efficient technical and economic implementation of numerous new projects. Development and widespread introduction of domestic innovative technologies, equipment and materials are becoming the concerns of vital importance.

Considering the role of MRC in the Russian economy, growing complexity of the resource base, sanctions from a number of states, the current situation in the innovative sphere may hardly be accepted as satisfactory. The indicators of the economic development testify to the existing discrepancy between the role of MRC in the Russian economy and the results of innovation policy of domestic extracting companies.

Keywords: mineral resource complex, knowledge, patents, innovation, technologies, state regulation, oil and gas extraction, region.

The article was written with financial support of the Russian Science Foundation (grant no. 19-18-00170).

Research area: economics.

Citation: Kryukov, V.A., Tokarev, A.N. (2019). Contemporary features of innovative development of the Russian mineral resource complex. J. Sib. Fed. Univ. Humanit. Soc. Sci., 12(12), 2193-2208. DOI: 10.17516/1997-1370-0518.

(C) Siberian Federal University. All rights reserved

* Corresponding author E-mail address: valkryukov@mail.ru

ORCID: 0000-0002-7315-6044 (Kryukov); 0000-0002-0597-3229 (Tokarev)

This work is licensed under a Creative Commons Attribution-NonCommercial 4.0 International License (CC BY-NC 4.0). 
An important feature of the mineral resource complex in its current state is a swift notional transformation concerning types and sources of raw materials involved in the economic circulation. This factor considerably alters the impact of new knowledge and technologies on the process of converting various and less homogenous (as to composition, used technologies, interaction of participants) types of resources and their sources. The transformation requires institutional conditions that may facilitate generation of new knowledge, technologies, approaches and their implementation practices.

\section{Increasing complexity of mineral resource extraction and necessity of innovative development}

Nowadays, in the world as a whole and also in Russia, the conditions for extracting mineral resources are becoming considerably more complicated driving up costs and risks for participants of such processes. The situation is quite typical for the oil and gas sector (OGS) of Russia:

- extraction of hydrocarbon resources in new regions and provinces (e.g. in East Siberia) requires building of capital intensive and vast transportation facilities;

- development of oil and gas deposits on the sea bed demands participation of Russian and foreign investors, development and utilization of innovative technologies;

- extraction of fossil resources from mature and new provinces necessitates extensive use of augmented reservoir recovery methods, new technologies for reaching deeper horizons, primarily in West Siberia and Volga basin (Kryukov, Tokarev, Shmat, 2016).

The analysis of institutional aspects of developing ever more complex mineral resources in its interaction with the knowledge of economy development is the new mainstream direction of research both in Russia and abroad. A vast range of organizations such as research institutes, universities, research centres, departments of commodity corporations, consultants and governmental organizations are all engaged in the study of organizational problems arising in generation of new knowledge.

Thus, researchers from the Massachusetts Institute of Technology (USA) study the way economic conditions impact current techniques of extracting hard-to-reach oil and gas resources. A special role in this is played by generation of new knowledge and economic conditions influencing the operation of science-intensive companies (Kleinberg et al., 2016).

A study carried out by McKinsey demonstrated that the modern economy is radically different not only in the way it employs exploration and extraction approaches to natural 
resources, but also in the way it consumes them. Price shocks, in particular, no longer produce such significant impact as they used to. Principal reasons are technological innovations, robotechnics, data processing technologies, as well as changes of client behaviour. The result of the above is that extraction companies have at their disposal a whole range of technological opportunities for raising their efficiency. This takes place due to a growing list of utilized technologies and possibilities provided by the modern service sector and breakthroughs of processing natural resource data (Beyond the supercycle, 2017).

In the Trondheim Technical University (Norway), the program 'Better Resources Utilization' studies how to employ a scientific and technological potential for solving problems of rational utilization of oil and gas resources. The principal goal of the research is development of technologies and organizational solutions (business models) aimed at building up the oil and gas sector in times of low prices and growing ecological demands (Better Resource Utilization..., 2016).

The Cardiff University (UK) studies interactions of research and education establishments with business in the modern environment of knowledge economy, in particular, transformation of forms and frameworks of such interaction (Cooke, Leydesdorff, 2006). Representatives of this university study problems of interaction between various types of companies participating in development of new types of fossil sources (primarily shale ones). This research is focused on forms of interaction between science-intensive service and extraction companies on various stages of resource extraction (Thomas, Pidgeon, Bradshaw, 2018).

It is worth noting that transformation of the Russian resource sector in the environment of evolving knowledge economy has its own specific features. It is being shaped not only (and, probably, not as much) by the global trends. This transformation bears a specific imprint of institutional conditions currently prevailing in Russia, as well as peculiarities of its mineral resource base. Thus, the mechanisms of state regulation over the MRC, both those used now and still under development, need to consider those factors.

\section{Trends of innovative development in the MRC of Russia}

Launch of the innovation process, in the industry as a whole and MRC in particular, is usually coupled with considerable costs. Two approaches to innovative development may be considered in a simplified manner: purchase of ready-to-use equipment or conducting own R\&D cycle followed by delivery of new technologies (bypassing the 
stage of acquiring ownership titles to intellectual property - patents for invention and utility models). The first approach is fast and simple, although it presumes catchingup development. The second one is longer, more complicated and fraught with risks including those concerning the obtained results. But potentially, it may deliver breakthrough technologies boosting the competitive level of companies or industries.

Which option is being selected by Russian companies of MRC and its backbone (in many ways such as contribution to economic development, export revenues, demand for innovation) segment - oil and gas complex? Are the MRC creating articles of intellectual property capable to deliver breakthrough technological development? Does the innovation activity of MRC companies correspond to the status of its resource base? To what extent may innovative technologies generated by the MRC cover the existing requirements? The answers to these questions largely determine the prospects of Russian MRC development, its place on the global markets and its role in transition of the Russian economy towards the innovative path of development.

\section{Costs of technological innovation}

Expenditures on technological innovations (at current prices) for the type of economic activity 'extraction of natural resources' (MRC) have a tendency to grow (Table 1). These expenditures of MRC make up 10-15\% of the total volume of spending on technological innovation in Russia over all economic activities.

Table 1. Expenditures of industrial enterprises on technological innovation, billion Roubles

\begin{tabular}{|c|c|c|c|c|c|c|}
\hline Industrial complex & 2012 & 2013 & 2014 & 2015 & 2016 & 2017 \\
\hline MRC & 87.8 & 94.5 & 123.9 & 125.6 & 136.7 & 184.8 \\
\hline OGC & 79.4 & 82.3 & 112.7 & 118.9 & 114.3 & 164.7 \\
\hline Share of OGC, \% & 90.5 & 87.1 & 90.9 & 94.7 & 83.6 & 89.1 \\
\hline
\end{tabular}

Source: Unified Interdepartmental Statistical Information System. Available at: https://fedstat.ru/ indicator $/ 58760$

The principal share in the cost structure is purchase of machines and equipment (about $2 / 3$ of expenditures, $68 \%$ in 2017). The research and development itself takes up only around $20 \%$ of technical innovation costs (18.7\% in 2017) (Russian statistical yearbook, 2019). One cause of nominal expenditure growth is rising prices of the 
purchased equipment also due to a falling rate of Rubble. So, we cannot talk about a substantial real increase in costs on technological innovation on behalf of MRC companies.

The main share of costs in MRC is borne by the oil and gas sector companies (OGC) - 83-94 \% in 2012-2017. A large share falls on the oil and gas services (services provided during extraction of resources). The share of services in technological innovation costs reached $40.5 \%$ in 2017. This high figure of services in costs is also attributed to purchase of foreign equipment for extraction of nonconventional deposits and ever more problematic fossil resources on the territory of Russia.

\section{Innovation activity of MRC}

Unfortunately, Russian companies are scaling down the innovation activity: there are a falling number of companies engaged in technological, organizational and marketing innovation. This is observed for the Russian economy as a whole and for MRC in particular. Thus, the share of innovation active companies in Russia went down from $10.4 \%$ in 2011 to $8.4-8.5 \%$ in $2016-2017$ while in MRC - from $8.4 \%$ in 2011 to $6.1 \%$ in 2017. At the same time processing works having reached the level of $13-14 \%$ in 2010-2016 raised this indicator to $15.1 \%$ in 2017.

Some indexes demonstrating innovation development of MRC are consistently lagging behind the average for Russia (i.e. for the entire economic activity) and even more that of the processing industries. It is also alarming that the MRC dynamics suggests a trend towards falling indexes for the innovative development (Fig. 1).

The underperformance of MRC is evident in the relative share of innovative goods: in 2017 this figure for MRC was $3.9 \%$ whereas in Russia on average it was $7.2 \%$ ( $8.6 \%$ in processing industries). What is more, Russia in general and its MRC demonstrate a falling trend: for Russia - down from $9.2 \%$ in 2013 to $7.2 \%$ in 2017 , while for MRC - down from $7.2 \%$ in 2014 to $3.9 \%$ in 2017. To some degree this change may be attributed to sanction pressure that is substantially targeting highly technological oil and gas extraction.

As for a relative share of organizations engaged in technological innovation the MRC is behind average performance indicators for Russia and much more behind processing industries. Thus, in 2017 only $10 \%$ companies of the oil and gas sector were engaged in technological innovation. It is also necessary to consider a peculiar organizational structure of the MRC in Russia as a whole and in OGS in particular. According to the Russian Ministry of Energy there are 288 organizations that carry out 


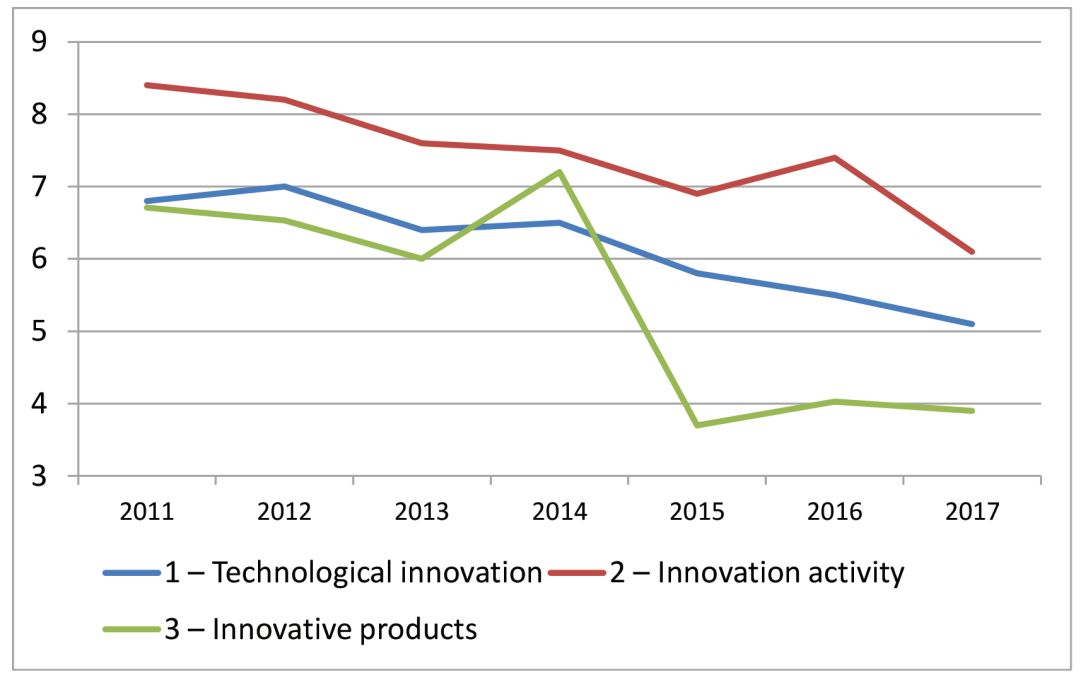

Fig. 1. Indexes of innovation activity of MRC, $\%$

Note. 1 - a share of organizations engaged in technological innovation, $\% ; 2$ - innovation activity of organizations (a share of organizations pursuing technological, organizational and marketing innovations of the total number of surveyed organizations); 3 - a share of innovative products, work and services in the total volume of delivered goods and services. Source: Unified Interdepartmental

Statistical Information System

extraction of oil and gas condensate on the Russian territory. Among them there are 104 organizations that are a part of vertically integrated companies and 81 independent companies.

Overall, there are just 30 companies engaged in technological innovation and these are all large companies. This tells us that small and medium Russian companies (a relatively low total number) hardly generate new knowledge and technologies that is required for processing difficult deposits (as opposed to international practice).

\section{Patent activity in MRC}

In what way do expenditures on technological innovation mostly tied to R\&D correlate with acquisition of title documents for intellectual property — patents on invention, utility models and computer software? The MRC may not be considered as a leader in the number of intellectual property rights (Table 2). As for 2017, a share of the MRC among organizations engaged in technological innovation in the total volume of inventions (for industry) was $9.7 \%, 6.1 \%$ — a share of useful prototypes and $11.4 \%$ a share in computer programs and databases. A principal share of patents for invention and useful prototypes belongs to processing industry organizations. 
Table 2. The number of current title documents and applications for intellectual property rights in organizations engaged in technological innovation in 2017

\begin{tabular}{|c|c|c|c|c|c|c|c|}
\hline \multirow{2}{*}{$\begin{array}{c}\text { Types of economic } \\
\text { activity }\end{array}$} & \multirow{2}{*}{ Unit } & \multicolumn{3}{|c|}{ Existing titles of protection } & \multicolumn{3}{|c|}{ Number of applications } \\
\hline & & Inventions & $\begin{array}{l}\text { Utility } \\
\text { models }\end{array}$ & Programmes* & Inventions & $\begin{array}{l}\text { Utility } \\
\text { models }\end{array}$ & Programmes* \\
\hline Industry & Piece & 17680 & 6424 & 2727 & 1464 & 745 & 551 \\
\hline $\mathrm{MRC}$ & Piece & 1717 & 394 & 310 & 179 & 63 & 81 \\
\hline $\begin{array}{l}\text { - a share of MRC in } \\
\text { industry }\end{array}$ & $\%$ & 9.7 & 6.1 & 11.4 & 12.2 & 8.5 & 14.7 \\
\hline OGC & Piece & 1578 & 360 & 285 & 171 & 57 & 62 \\
\hline $\begin{array}{l}\text { - a share of OGC in } \\
\text { MRC }\end{array}$ & $\%$ & 91.9 & 91.4 & 91.9 & 95.5 & 90.5 & 76.5 \\
\hline Service & Piece & 46 & 6 & 4 & 3 & 3 & 0 \\
\hline $\begin{array}{l}\text { - a share of service in } \\
\text { MRC }\end{array}$ & $\%$ & 2.7 & 1.5 & 1.3 & 1.7 & 4.8 & 0,0 \\
\hline Processing & Piece & 15627 & 5695 & 2092 & 1226 & 650 & 435 \\
\hline - a share in industry & $\%$ & 88.4 & 88.7 & 76.7 & 83.7 & 87.2 & 78.9 \\
\hline
\end{tabular}

Note: Programmes* - software programmes for computers, databases, topologies of integral chips. Source: (Indexes..., 2019).

Within the MRC of Russia the largest number of titles of protection for intellectual property belongs to the OGC companies: over $90 \%$ of patents for invention and utility models. A similar picture is for patent applications. Thus, the role of the MRC in the industry and the place of the OGC in the MRC is dynamically stable. The MRC has a rather low share of service in the total number of existing titles and applications.

\section{The dynamics of developed cutting edge production technologies in the Russian MRC}

Expenditures on research and development, obtained patents on invention, utility models are all requisite foundations for developing new technologies. In what measure do the new knowledge, ongoing research and development turn into practical results new technologies for the MRC?

Certain conclusions may be drawn from analysing the number of delivered cutting edge production technologies $(\mathrm{CEPT})^{1}$ in the mineral resources complex. To start with, the total number of CEPT is quite low — at most 25 released technologies (in 2016),

Cutting edge production technologies - technologies and technological processes (including the equipment required for their implementation) enacted via computer or based on microelectronics and used for design, manufacturing or processing of deliverables (goods and services). 


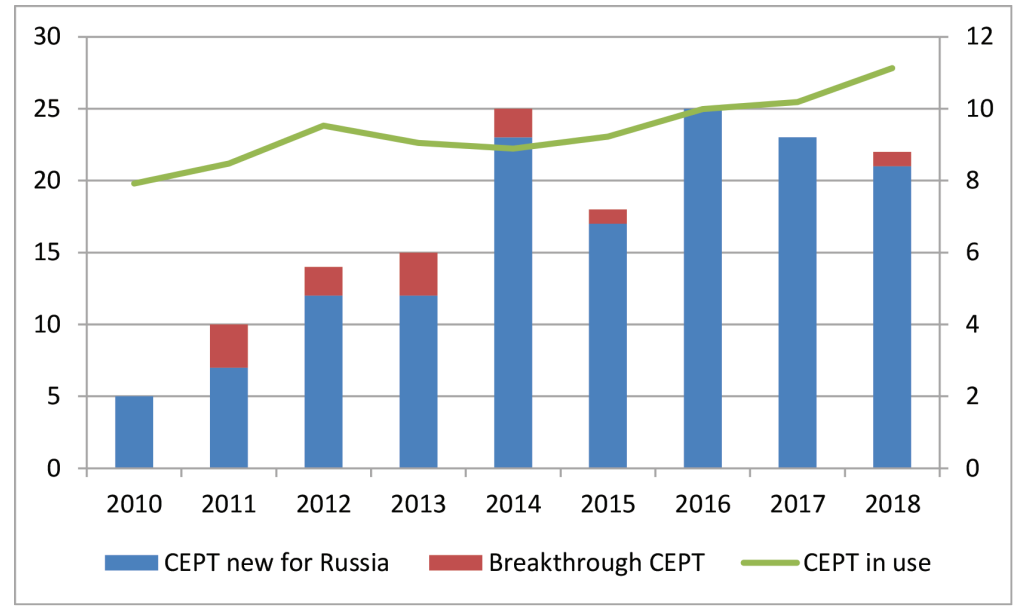

Fig. 2. The dynamics of used (thousand pieces, the right axis) and released cutting edge production technologies (pieces, the left axis) in the MRC of Russia. Source: Technological development of industries of economy. Federal service of state statistics.

Available at: https://www.gks.ru/folder/11189

which is almost 20 times less than, for instance, in the 'processing industries' category (Fig. 2).

The number of released cutting edge production technologies for Russia (i.e. not having domestic substitutes) in the MRC in the period after 2010 is rather unstable. After 2014 there is a trend of a growing number of such technologies developed in the MRC (compared to 2010-2013). This is related, among other things, to the import replacement policy after sanctions that mostly targeted extraction of unconventional oil deposits and implementation of the sea bed projects.

The number of CEPT in the MRC (versus 2010) has grown by more than on average in the economy: by 4-5 times in 2016-2018 (compare to 2010) while in the economy as the whole it was $60-80 \%$. One should, however, keep in mind the total low number of CEPT released in the MRC. It is also worth noting that the principal share of CEPT (70-90\%) within the MRC is created in the OGS.

From the point of view of global competitiveness it is crucial that the MRC of Russia does not develop revolutionary new cutting edge production technologies, that is technologies that may not be substituted by domestic or foreign ones, that are released for the first time and have brand new characteristics that answer the latest requirements. In the period of 2010-2018 the entire MRC delivered just 12 such technologies or, roughly, one per year. And this does not happen every year: in 20162018 just one such technology was released (Fig. 2). In 2011 and 2013, there appeared 
three CEPT per year, which highlights the general falling trend of (already pitiful) number of breakthrough CEPT released in the MRC of Russia.

Moreover, this is happening against the background of a growing trend over all types of economic activity: from the level of 102 CEPT in 2010 to 192, 190 and 181 technologies respectively in 2016, 2017 and 2018.

It may be interesting to compare the number of CEPT that are under development and the number of CEPT in use in the MRC in Russia. In total, in the period from 2010 to 2018 (9 years) all of the MRC in Russia developed 157 of new CEPT (on average about 17 technologies a year). At that, the number of CEPT in use over the same period increased by over 3 thousand. This increase proves a considerable demand for the new technologies from the Russian MRC in the circumstances of the deteriorating resource base.

On the whole, based on the analysis of the above trends it appears reasonable to assume that the Russian MRC with some incentives and under certain conditions may be capable to produce new technologies for Russia. However, development of technologies that have no foreign alternatives is a rare exception for periods embracing several years.

\section{Evaluation of patent activity: developing utility models for OGC}

The analysis presented earlier demonstrated that it is necessary to significantly increase the innovation activity of the MRC companies in Russia. At the same time, we observe a current explosive growth abroad in the key directions of the MRC development. Thus, in the 2000's, the number of patent application in technologies of shale oil and gas extraction grew by leaps. At the level of patent families (clusters of patent applications connected to one object and submitted in different countries) the growth in 2000-2012 reached $188 \%$. The number of such patent families totalled four thousand (Patent Landscape Report, 2016).

The majority of patent applications were submitted by companies from China, USA and Japan (over $83 \%$ of the total number). From 2000 to 2012 the number of applications for shale extraction in China grew by $2000 \%$. The most active participants are extraction and service companies - the Chinese Sinopec (371 patent families), Japanese JX Nippon Oil \& Energy (209), American Exxon Mobil (141), Halliburton (140) and Schlumberger (100 patent families). The companies from China, USA and Japan are the principal generators of patents on technologies of extracting shale oil 
and gas. At the same time, the largest oil and gas service companies are most active in patenting technologies applicable to drilling wells and their high tech support.

Introduction of measures and schemes to stimulate innovative processes within the MRC of Russia (with consideration of the role and peculiarities of the industrial complex) demands answers to several questions, such as:

- what companies and organizations - extraction, service, machine-building, higher education establishments, scientific research institutes - generate new knowledge and innovations for the MRC?

- what is the spatial structure of new knowledge generation? To what extent is this connected to places of extraction?

- how does the current situation in the Russian MRC correlate with the world practice and latest trends?

A regional and "industry-specific" structure of generating new knowledge in the OGC has been analysed at the example of patents on the utility models — similar to inventions of the non-material objects of intellectual rights (technical solutions) related to devices. For the utility models, Russia sets less strict terms for the patents registration, including time frames and simplified procedures of review. Such patents also have a shorter validity period (10 years).

We have used the database of the Federal Institute of Industrial Property (formulas of the Russian utility models). Our review considered the sub-class of international patent classification E21B — "Drilling ground or mountain strata; extraction of oil, gas..." that quite amply specifies the process of generating knowledge and technology development in the OGS. This sub-class includes methods and devices for drilling; repair and maintenance of oil wells, drilling equipment, extraction of liquid and gaseous media; drilling rigs; automatic management and regulation; measurements and testing during extraction; drilling tools.

\section{The "industry-like" structure of patents for utility models}

In the current conditions, generating knowledge abroad, as well as development and utilization of most new technologies in exploration and extraction of fossil fuel, take place either on the initiative or with the active participation of the service companies. Oil and gas service companies are playing a key part in obtaining about $80 \%$ of patents having a direct link to fossil extraction technologies (Perrons, 2014). As the knowledge is the utmost strategic resource and education is the most important process, the role and weight of oil and gas sector in the global practice are growing in 


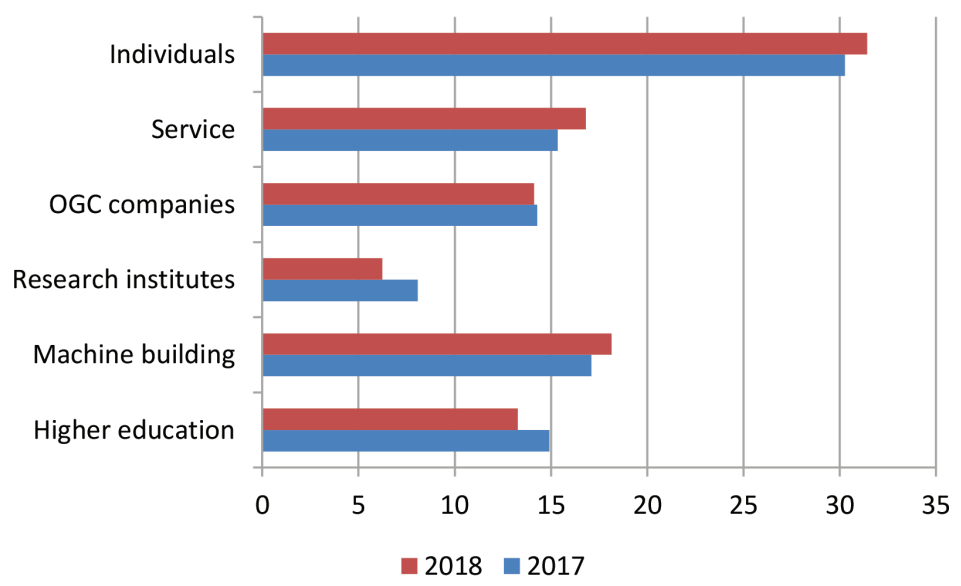

Fig. 3. The "industry-like" structure of patents for utility models, $\%$

many aspects: from generation of new knowledge to participation in resolving social and economic problems of the resource territories (Lundvall, 2004).

At present in Russia, most patents on utility patents for OGC belong to individuals. Higher education establishments, extraction and oil and gas service companies roughly represent equal parts. Scientific organizations are somewhat behind the above organization categories (Fig. 3).

Thus, in Russia (as opposed to the modern international practice) the oil and gas service may not be considered as an absolute leader from the point of view of generating new knowledge and development of new technologies. This is partly explained by the fact that Russia has got no major companies of the Halliburton or Schlumberger level. The domestic service companies (even larger ones by our standards) do not in fact pursue research and development and have got no scientific-technical centres of their own. Quite often they cannot compete in the technical issues with large foreign service.

\section{The regional structure of utility model patents}

Another serious aspect of the new knowledge generation (in this case related to the development of utility models) is a spatial structure. To what extent is this connected to large research centres or regions where extraction of oil and gas is taking place?

Under present conditions the regional innovative systems are becoming all the more critical factors of the socio-economic development of given territories and states in general. Various approaches are being implemented for shaping territorial innovation models (Moulaert, Sekia, 2003). Russian resource regions following the global trend 
are attempting to create their own innovation systems. Considering the importance of the oil and gas sector for the Russian economy and significance of large vertically integrated companies the resource rich subjects of federation are facing challenging tasks of stimulating innovation processes.

That is why the problems of incorporating the OGC (as the most important consumer, carrier and generator of new knowledge and technologies) into innovation systems of regions is becoming ever more urgent. The specifics of the resource sector is such that development of new technologies, their testing and implementation require close 'tying to' definite development targets - deposits and reserves. At the same time the effect of geographical proximity to the MRC installations is a crucial (and even more important than in many other sectors) factor of launch and promotion of innovation processes (Shearmur, 2010).

The analysis of patent activity (as applied to the utility models) demonstrates that a major share of these patents (around $50 \%$ ) can be attributed to the Volga Federal Okrug (FO), mostly to Tatarstan, and some to Bashkortostan, Perm Territory, Samara Region and Udmurtia. A sizeable share in the list of patent owners is taken by regional higher education establishments - Almetyevsk State Oil Institute, Ufa State Oil Technical University, Bashkir State University (Fig. 4).

A major part of patent owners for the utility models is registered in the Central FO (mostly in Moscow and Moscow Region). And the main oil and gas extraction region - Ural — in the number of patents is far behind the leader (Volga FO). Notably, the main patent owners in the Ural FO are Tyumen (south) and Sverdlovsk Region

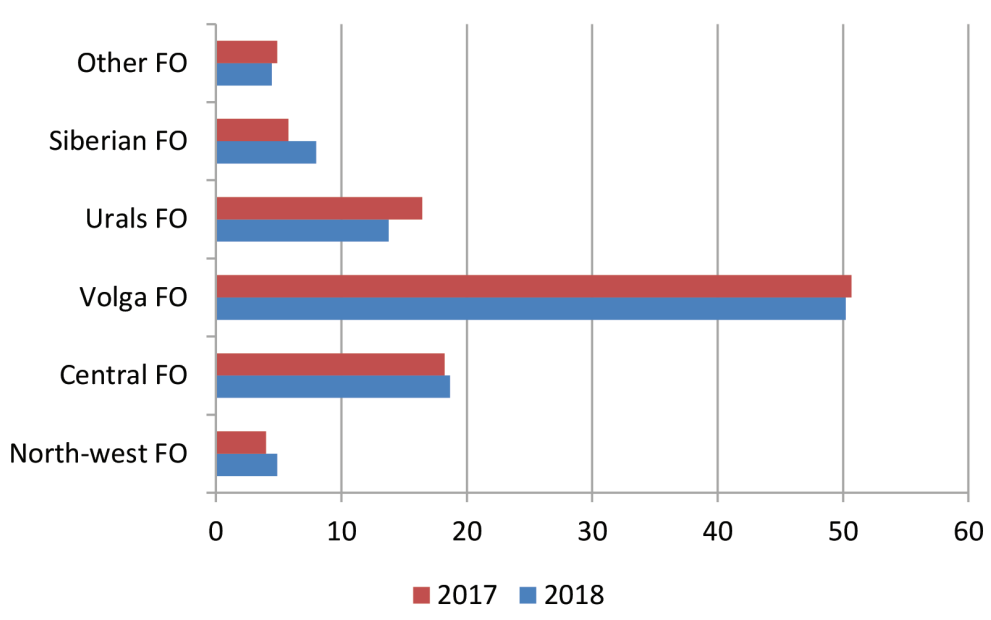

Fig. 4. Spatial structure of utility model patents, $\%$ 
and not the extracting regions - Khanty-Mansiysk and Yamalo-Nenets autonomous okrugs.

Among the Russian oil and gas extracting companies the most active in patenting the results of its intellectual operation is "Tatneft". Among higher education establishments and design institutes, the representatives of Tatarstan, which is mainly explained by the "Tatneft" policy, are also quite active. Those developing new technologies are "TatNIPIneft", TatNIIneftmash" and the service company "TNGGroup". The partners of the company participating in the technological development projects are the Academy of Sciences of Tatarstan, the Institute of Microbiology of RAS, and the All-Russian Research Institute of Hydrocarbon Raw Materials (Kazan). This setup gives evidence about a network model of innovation development that is being shaped in Tatarstan. Potentially this model is regarded as the most rational and farsighted.

With a network model, the innovation activity mostly features localized interactive education. Within its scope local companies closely cooperate with each other. In these circumstances innovation development has a more systematic character due to participation of regional authority organs. Such cases also widely involve the local innovation infrastructure, research and design institutes (Kryukov, Tokarev, 2018).

On the whole, the 'industry-specific' and regional structure of patent activity in the OGC of Russia to a large degree is determined by one of the largest oil and gas extraction company PAO "Tatneft". Its high innovation activity is proved by a large number of title documentation on inventions, utility models and computer software programmes. PAO "Tatneft" owns over 1400 of currently valid patents. The company concludes license agreements on granting rights of using results of its intellectual activity - inventions, utility models and software programmes.

The company appears to be a leader not only on the Russian, but also on the European level. Thus, in 2015 PAO "Tatneft" took the first place among European innovators in the OGC in the rating by Thomson Reuters (Top 5 Petroleum \& Gas Exploration Innovators - Europe, 2010-2014) (The Future..., 2015). The evaluation of the technological development results was conducted on the basis (among other things) of registered patents. The factors that secured the leading position of PAO "Tatneft" in generation of new knowledge and innovative technologies development include:

- a dire need for innovation connected with a necessity of developing a complicated resource base. The largest oil deposit - Romashkino Field - to a large degree is exhausted: most oil wells have low productivity and the extracted product has a high- 
water content. Maintaining extraction volumes on a high level requires involving into circulation of hard-to-reach deposits, including bituminous resources and Domanic strata;

- interaction of PAO "Tatneft" with a whole range of regional players (companies and organizations) mostly small and medium oil producers, local higher education establishments and institutions;

- active internal policy of the company in the innovation sphere, including work protecting intellectual property.

\section{$* * *$}

The place and the role of the MRC in the economy of Russia, the complication of the resource base determine the necessity of the active innovation policy of the resource companies. Unfortunately, at present the MRC may not be considered as a leader of innovation activity. The number of breakthrough production technologies is negligible and this is bringing about dire risks in the circumstances of sanction pressures and current demand for new technologies.

It should be pointed out that a weak position of the domestic oil and gas service in the innovative development does not correspond to the contemporary world practice. Support and stimulation of service development may become a major factor of technological development in the MRC of Russia.

Technological development of the MRC that matches modern challenges requires closer interaction of a wide range of innovative process participants: extraction companies, service, scientific organizations, higher education establishments, machinebuilding companies. Such aggregation of effort may become an important starting point for more fruitful work in the MRC innovation sphere.

Deteriorating conditions of developing mineral resources lead to higher costs and consequently to lower competitiveness of the Russian MRC and demand:

- changes in the system of state regulation of mineral development — in licensing, tax, scientific-technical policies, in regulation of monopoly activities stimulating the MRC towards an innovative development trajectory;

- state participation in formation of organizational structures targeting creation of new technologies and their transfer;

- establishing new forms of cooperation among users of mineral resources in order to combine efforts, reduce costs and effectively distribute risks of implementation of new projects widely using new technologies. 
A credit worthy demand on behalf of the MRC for new knowledge and technologies should become a factor transforming the MRC into one of the most important 'locomotives' of the innovative development of the Russian economy as a whole.

\section{References}

Better Resource Utilization in the 21 ${ }^{\text {st }}$ century (BRU21) (2016). NTNU Strategy for Oil and Gas. Norwegian University of Science and Technology, Norway, 76 p.

Beyond the supercycle: how technology is reshaping resources (2017). McKinsey Global Institute, 24 p.

Cooke, P., Leydesdorff, L. (2006). Regional Development in the Knowledge-Based Economy: The Construction of Advantage. In Journal of Technology Transfer, 31(1), 5-15. DOI: 10.1007/s10961-005-5009-3.

Indicators of innovative activity. 2019 statistical digest (2019). L.M. Gokhberg, K.A. Ditkivski, I.A. Kuznetsova and others; National research university "Higher school of economics", Moscow, NRU HSE, 376 p.

Kleinberg, R, Paltsev, S., Ebinger, C., Hobbs, D., Boersma, T. (2016). Tight Oil Development Economics: Benchmarks, Breakeven Points, and Inelasticities. MIT Centre for Energy and Environmental Policy Research. CEEPR WP 2016-012, 27 p.

Kryukov, V.A., Tokarev, A.N. (2018). Spatial Dynamics of the Oil and Gas Field Services Sector: Global Trends and Lessons for Russia. In Regional Research of Russia, 8(3), 248-257. DOI: 10.1134/S2079970518030036.

Kryukov, V.A., Tokarev, A.N., Shmat, V.V. (2016). How Can We Preserve Our Oil and Gas "Hearth"? In Problems of Economic Transition, 58 (2), 73-95. DOI: 10.1080/10611991.2016.1166899.

Lundvall, B.-A. (2004). The economics of knowledge and learning. Product Innovation, Interactive Learning and Economic Performance (Research on Technological Innovation, Management and Policy, 8). Christensen, J., Lundvall, B.A. (ed.). Emerald Group Publishing Limited, 21-42.

Moulaert, F., Sekia, F. (2003). Territorial Innovation Models: A Critical Survey. In Regional Studies. 37(3), 289-302. DOI: 10.1080/0034340032000065442

Patent Landscape Report - Shale Oil and Gas (2016). Canadian Intellectual Property Office, $32 \mathrm{p}$.

Perrons, R. (2014). How innovation and R\&D happen in the upstream oil \& gas industry: Insights from a global survey. In Journal of Petroleum Science and Engineering, 124, 301-312. DOI: 10.1016/j.petrol.2014.09.027. 
Russian statistical yearbook. 2018 (in Russian and English) (2019). 895 p.

Shearmur, R. (2010). Space, place and innovation: a distance-based approach. In Canadian Geographer, 54(1), 46-67. DOI: 10.1111/j.1541-0064.2009.00302.x.

The Future Is Open: 2015 State of Innovation. Thomson Reuters (2015), 80 p.

Thomas, M., Pidgeon, N., Bradshaw, M. (2018). Shale development in the US and Canada: A review of engagement practice. In Extractive Industries and Society, 5 (4), 557-569. DOI: 10.1016/j.exis.2018.07.011.

\title{
Современные особенности инновационного развития минерально-сырьевого комплекса России
}

\author{
В.А. Крюков, А.Н. Токарев \\ Институт экономики и организациии \\ промышленного производства СО РАН \\ Россия, 630090, Новосибирск, \\ пр. Академика Лаврентьева, 17
}

\begin{abstract}
В настоящее время минерально-сырьевой комплекс (МСК) играет ключевую роль в российской экономике. В условиях усложнения ресурсной базы и становления экономики знаний его устойчивость, а также конкурентоспособность будут во многом зависеть от инновационного, технологического развития. Все более важным фактором развития для МСК становятся возможности использования новых знаний и технологий: владение правами на результаты интеллектуальной деятельности, на технологии, позволяюшие вовлекать в хозяйственный оборот трудноизвлекаемые ресурсы, добывать все более сложные запасы.
\end{abstract}

Проведенный анализ показал, что сегодня в российском МСК наблюдается низкая инновационная активность, нехватка новых технологий, без которых практически невозможна технически и экономически эффективная реализация многих новых проектов. Разработка и широкое использование отечественных инновационных технологий, оборудования, материалов становятся все более жизненно необходимыми задачами.

Учитывая роль МСК в экономике России, усложнение ресурсной базы, санкиии со стороны ряда стран, существующее положение в инновационной сфере вряд ли можно признать удовлетворительныл. Показатели инновачионного развития свидетельствуют о имеющем место противоречии между ролью МСК в экономике России и результатами инновационной политики отечественных добывающих компаний.

Ключевые слова: минерально-сырьевой комплекс, знания, патенты, инновации, технологии, государственное регулирование, добыча нефти и газа, регион.

Статья подготовлена при финансовой поддержке Российского научного фонда (грант № 19-18-00170).

Научная специиальность: 08.00.00 - экономические науки. 